\title{
Impact of Service Quality and Customer Satisfaction: Evidence from Banking Industry
}

\author{
Jawad Khan ${ }^{* 1} \&$ Amanullah Khan ${ }^{2}$ \\ ${ }^{1,2}$ Institute of Business and Management Sciences, The University of Agriculture Peshawar, Pakistan
}

\begin{abstract}
This study aims to investigate impact of service quality on customer satisfaction. Information data were collected by questionnaires from two hundred customers of four private sector banks located in Peshawar district using convenience sampling technique. Results indicate that customer service quality has a positive influence on customer satisfaction.
\end{abstract}

Key words: Customer Service Quality (Tangibility, Reliability, Responsiveness, Assurance, Empathy), Customer Satisfaction.

\section{Introduction}

The role of customers and consumers is changing in progressive business environment day by day (Prahalad et al., 2000). Quality of service in the changing business environment has become the top priority for organizations. It is important for businesses to emphasize on customerfocused strategy in order to achieve competitive advantage and succeed in today's market (Taylor and Baker, 1994).

It is generally understood that the quality of service is the indicator of how efficiently the services are provided to meet consumer needs (Santos, 2003). Quality in services is the most imperative factor that is directly linked to the success of the company. Cronin Jr and Taylor (1992) found that customer satisfaction is the service quality measure of any organization.

The company's service quality should be in line with customer expectations (Zeithaml et al., 1988). The quality of services and products must be considered as strategic variables to gain efficiency and effectiveness in business transactions or operations (Anderson and Zeithaml, 1984). In providing outstanding service quality, service providers need to balance market competition (Bharati and Berg, 2005; Yoo and Park, 2007).

A list of ten performance measures for customer service (tangibility, reliability, responsiveness, courtesy, ability to communicate, credibility, security, customer access and understanding) was published by Parasuraman et al. (1985). With these ten attributes, the focus group performed their analysis in service oriented firms and customers resulting in further distillation of the SERVQUAL scale into five major customer service quality components, i.e. responsiveness, tangibility, reliability, empathy and security (Parasuraman et al., 1991, 1985).

*Corresponding author.

Email: jawadmarwat1@gmail.com

http://www.jbrc.pk

(C) Jinnah Business Review 
Quality in service not only enables them to fulfill the current desires but also to foresee the future needs of customers. Afterwards, it reinforces customer satisfaction and loyalty level towards these organizations (Wisniewski, 2001; Zeithaml et al., 1988). Since the essence of the services is intangible, it becomes very difficult for the consumer to recognize and determine the level of customer service they provide (Bitner, 1992; Lovelock and Lovelock, 1996). Several researchers have been intrigued by the association between quality in service and satisfaction level of customer. The availability of good service value precedes satisfaction (Yee et al., 2008). There is meaningful association between quality service and customer satisfaction (Anderson and Sullivan, 1993).

Customer service appears to have a direct impact on customer satisfaction and organizational attachment (Chau and Kao, 2009). Customer satisfaction is now regarded by companies as a major component of corporate strategy (Zahorik and Rust, 1993). The key measure in determining customer satisfaction is the customer's own approach regarding services that have been provided (Zeithaml et al., 1996). The most essential feature of any service organization is customer satisfaction, which is directly proportional to the value of the services provided (Bolton and Drew, 1991). High customer satisfaction results in positive behavioral outcomes like commitment, retention and generation of mutually beneficial association (bond) among the service offered and the consumer (Newman, 2001).

In service sector, financial and banking services are almost completely dependent on high customer satisfaction levels to achieve growth and competitive advantage (Mishkin, 2007). The banking sector in developing countries has undergone many changes in order to compete with global standards (Yavas et al., 1997). Significant links were found within the banking sector between quality in service and satisfaction level (Blanchard and Galloway, 1994). Banks have acknowledged that providing quality services is essential to growth and survival in the advanced international and competitive banking world (Wang et al., 2003).

Most researches / studies have concentrated on the quality of customer service in developed countries banking sector, but nowadays most studies concentrate on developing countries (Angur et al., 1999). In today's competitive environment, stability and continuous growth in service quality are keys to survival (Haq and Muhammad, 2013).

The research should draw attention in particular to the fact that while the process must be structured in compliance with international service quality standards, customer satisfaction is integrated into any strategic planning. Current studys purpose is to record the quality of service in the Pakistani banking industry.

\section{Literature Review}

\subsection{Customer Service Quality}

Customer service is considered as the main instrument of service related organization, which is achieved through the collective efforts of all functions of the organization (Stevens and Johnson, 2016). Ample research has been conducted to quantify the role of employees working in a service organization's various departments, in collectively providing the required level of customer service (Oliva and Sterman, 2001).

Typically, quality of customer service has been defined as the overall level of customer satisfaction with the services provided (Johns, 1992). The quality of customer service is usually seen as a measure of how well the services offered suit the customer's expectations (Santos, 2003). 
The value of customer service is defined as "the outcome of an evaluation process in which the users analyze their perceptions with the service that are provided" (Grönroos, 2001).

Service quality is the customers overall opinion of the deliverables that are provided as compared to the customers expectation when he initially made the purchase (Grönroos, 2001). Customer service quality is an instinctive assessment that the customer makes to assess service quality that they would like to obtain as compared to what they really acquire (Gefen, 2002).

\subsection{Customer Satisfaction}

Customer satisfaction usually means achieving the degree of satisfaction that consumers expect after making their purchase (Oliver, 1997). The customers opinion of any services meeting his/her requirements, which were purchased from the same brand in the past, consequently motivating him/her to repeat the purchase again; or where he/she may consider becoming a potential buyer of the service from the same brand again at any time in future is known as supremacy of satisfaction (Loudon and Bitta, 1993).

Customer satisfaction is the foundation of competitive advantage for organizations and firms (Anderson et al., 1994). Zeithaml et al. (2000) explained that customer satisfaction is the measurement of customer needs, needs and preferences of services or products. Literature on customer satisfaction clearly shows that expectations are the most unchanging determinant of satisfaction and perceived quality (Kim, 2005).

The value perception theory states that satisfaction is an emotional reaction triggered by a system of cognitive assessment (Parker and Mathews, 2001). It was initially pointed out that happiness is correlated with goals met by success and disappointment arises when performance falls below expectations (Swan and Combs, 1976).

Theories of customer service quality and related practical results documented have established customer satisfaction as an almost tangible outcome rather than an unclear concept. Demonstration of satisfaction varies between individuals and items. Effective customer satisfaction almost invariably leads to repeat business for the service provider whether through the same customer or through recommendation to another potential buyer (Munteanu et al., 2010). This substantial benefit of providing quality customer service can be reliably measured, invoked and utilized in the form of business generated goodwill (ibid).

\subsection{Customer Service Quality and Customer satisfaction}

Performance of customer service and customer satisfaction are closely linked and considered directly proportional to one another (Chuah and Sri Ramalu, 2011). The assessment of products and services with the desired quality and standards after purchase is known as satisfaction (Kotler and Armstrong, 2012). Customer service is always applicable to achieve a high level of customer satisfaction, which is why reliability of customer service is generally considered a metric of satisfaction (Alolayyan et al., 2018; Gilbert and Veloutsou, 2006; Lee et al., 2000). Service quality is one of the most crucial factors of satisfaction. The most effective metric for assessing contentment of customer is performance of service quality (Kadir et al., 2011).

Although there is no evidence of any substantial correlation between observable revenue from the service environment and customer satisfaction, it is generally measured as the goodwill created by any company that has the potential to increase or attract more customers in the future (Jamal and Naser, 2002). These conclusions are in comparison with past research done by Wakefield and Blodgett (1999), and endorsed by Parasuraman et al. (1991). Customer service 
quality was accepted by a majority of researchers as a guide to customer satisfaction (Kassim and Abdullah, 2010; Kumar et al., 2010; Parasuraman et al., 1985). Expectations provide foundation for determining customers satisfaction (Oliver, 1997). Furthermore, expectations include information regarding probability of repurchase and future quality which will affect satisfaction level (Anderson et al., 1994).

Furthermore, multiple studies have shown that consistency of customer service has greater influence on satisfaction level of customer than expected expectations prior to purchase (Anderson and Sullivan, 1993). Quality customer service has a detrimental effect on customer satisfaction (Yee et al., 2008). Customer satisfaction is in fact considered a precedent of the quality of customer service (Bolton and Drew, 1991). The possible explanation given by Beerli et al. (2004) is that the idea of customer satisfaction is a measure of the value for money that the customer understands.

Although recent research has determined that customer perceptions may be challenged and modified by the services provided. The customer may not always be right as opposed to the age old slogan. The customer may not even be aware of what their requirements are and must be educated as to what he really needs as opposed to what he wants. Customer service quality almost invariably leads to greater levels of customer satisfaction with any product or service that is provided to the customer even if product or service is not what the customer initially asked for. In short, the customer service quality modifies or changes the customers requirements and reorients him towards the product or service that is provided versus the ones he initially set out to purchase.

\subsection{Theoretical Framework}

Figure represents the study's conceptual frame work. This study has one independent variable customer service quality with five dimensions (Tangibility, Reliability, Responsiveness, Assurance and Empathy) and a dependent, customer satisfaction variable)

\subsection{Customer Service Quality}

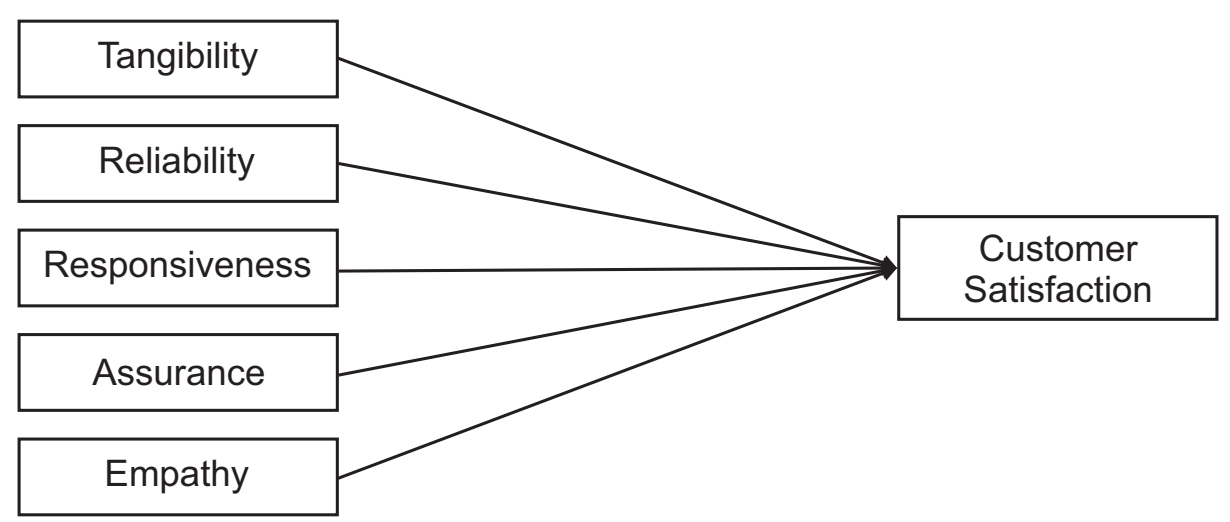

Figure 1: Theoretical Framework 


\section{Research Methodology}

\subsection{Population and Sample}

This research study considered all the private banks of Peshawar as population. The sampling units from the total population were selected through simple random sampling technique. The four banks were selected from the entire population i.e. Allied Bank Limited (ABL), Habib Bank Limited (HBL), MCB Bank Limited (MCB), United Bank Limited (UBL). The unit of analysis by equal proportion of 50 respondents and total 200 respondents were selected from the four private sector banks through convince sampling technique for the possible explanation of generalization of the selected sample.

\subsection{Instruments}

Questionnaires were the instrument for collecting data for this research project. Close ended questionnaires were used and divided into two subdivisions. The demographic section covered customers of banks age, education, gender and occupation. Variable section covered the responses of customers to the variables chosen for this study. Tangibility, reliability, responsiveness, assurance and empathy collectively Service quality measures were adapted from Cronin Jr and Taylor (1992); Grönroos (2001); Zeithaml et al. (1988), respectively. Customer satisfaction measures are adapted from Anderson and Zeithaml (1984); Cronin Jr and Taylor (1992); Jamal and Naser (2002); Yee et al. (2008); Zeithaml et al. (1988).

Descriptive statistics, Reliability assessment and Regression analysis has been used as statistical tools for this research.

\section{Results and Discussion}

\subsection{Reliability Valuation}

Internal constancy is a substantial issue when adapted scale is used in research study. As Streiner (2003) pointed that classical test theory has one of the essential tenets that measurement parameters should have a high extent of internal stability that is suggested by Cronbachs alpha. As per the table 1, the Cronbachs alpha values of the construct show that the instruments used were reliable as the values exceed 0.70 .

\subsection{Simple Linear Regression}

Table 2 shows and explains the relevant model to define connection between quality of customer service and satisfaction level of customer. $\mathrm{R}$ value is 0.805 , indicating a moderate level of customer satisfaction connection / correlation with customer service constructs. Value of R2 0.647 which shows $64.7 \%$ deviation in dependent variable has been described by independent variable.

\subsection{Coefficient values of the model}

Table 4 shows details regarding Customer Service Quality variables. Its identifiable that the constant and customer service quality significantly contribute as the values p.000 which 
Table 4.1: Correlation Analysis

\begin{tabular}{lcc}
\hline Constructs & No. of Items & Cronbach's Alpha \\
\hline Reliability & 5 & 0.701 \\
Assurance & 4 & 0.832 \\
Tangibility & 4 & 0.798 \\
Empathy & 4 & 0.833 \\
Responsiveness & 3 & 0.737 \\
Customer Service Quality & 20 & 0.859 \\
Customer Satisfaction & 4 & 0.760 \\
\hline
\end{tabular}

Table 4.2:

\begin{tabular}{lcccc}
\hline Model & R & R Square & Adjt. R square & Std. error \\
\hline 1 & 0.805 & 0.647 & 0.646 & 0.29437 \\
\hline
\end{tabular}

was $<.05$ to the model. Customer service quality was a substantial interpreter $(\mathrm{t}=19.069, \mathrm{p}=$ .000) of customer satisfaction concept. Customer service quality coefficient explains directly proportional association between dependent and independent variables.

Table 4.3:

\begin{tabular}{lccccc}
\hline & \multicolumn{3}{c}{ Unstandardized coefficients } & \multicolumn{3}{c}{ Standardized coefficients } \\
Model & B & Std. Error & Beta & t & Sig. \\
\hline Constant & 0.25 & 0.192 & - & 1.299 & 0.196 \\
Customer Service Quality & 0.965 & 0.051 & 0.805 & 19.069 & 0 \\
\hline
\end{tabular}

Table 4 indicates that coefficient of customer service quality is positive, which shows factual relationship exists between variables. Furthermore, $\mathrm{p} \& \mathrm{t}$-ratio for customer service quality is less than 0.05 indicating that customer service quality significantly effects customer satisfaction.

\subsection{Multiple Regression Analysis}

Multiple Regression model shows 65\% of disparity in Customer Satisfaction has been elaborated by independent variable Assurance, Responsiveness, Tangibility, Reliability, Empathy is showed according to the R2 value.

Table 6 shows positive value of each variable as well as significance value of each variable separately. 
Table 4.4: Multiple Regression Analysis

\begin{tabular}{|c|c|c|c|c|}
\hline Model & $\mathbf{R}$ & R Square & Adujsted R Square & Std. Error of the Estimate \\
\hline 1 & $0.806 \mathrm{a}$ & 0.65 & 0.641 & 0.29636 \\
\hline
\end{tabular}

Table 4.5:

\begin{tabular}{lccccccc}
\hline Model & \multicolumn{3}{c}{ Unstandardized Coefficients Standardized Coefficientst-ratio P-v.Collinearity Statistics } \\
& B & Std. Error & & Beta & Tolerance & VIF \\
\hline (Constant) & 0.279 & 0.198 & - & 1.409 & 0.16 & - & - \\
Reliability & 0.208 & 0.041 & 0.269 & 5.029 & 0 & 0.63 & 1.588 \\
Responsiveness 0.162 & 0.033 & 0.219 & 4.906 & 0 & 0.904 & 1.106 \\
Empathy & 0.231 & 0.049 & 0.254 & 4.679 & 0 & 0.613 & 1.631 \\
Tangibility & 0.183 & 0.041 & 0.215 & 4.44 & 0 & 0.768 & 1.301 \\
Assurance & 0.176 & 0.053 & 0.196 & 3.335 & 0 & 0.521 & 1.918 \\
\hline
\end{tabular}

The coefficient of various aspects of customer service quality is shown in Table 6 . This shows that each aspect of customer service quality is linked to customer satisfaction positively and significantly $\left(\mathrm{p}_{i} 0.05\right)$. In addition, positive change in any of the customer service quality dimensions will greatly enhance / increase customer satisfaction.

Furthermore, the values of tolerance and VIF suggest that there is no problem of multi collinearity in independent variable considered in the study.

\subsection{Hypothesis Assessments}

Table 7 shows that null hypothesis are rejected while alternate hypotheses are accepted in relation with the results of this study.

\section{Conclusion and Future Directions}

\subsection{Conclusion}

Purpose of current study was to attain better understanding of Customer Service Quality that is used for customer gratification in different private sector banks located in Peshawar. This study has been carried out through a literature review which led to the frame of reference and gathering of data. This study tries to find the essential features in the banking environment that can be acclimatized to analyze banks ' strengths as encountered by customers. Responsiveness and empathy unveil uppermost affirmative association with customer satisfaction. The basic 
Table 4.6:

\begin{tabular}{lcc}
\hline Hypotheses & $\beta$ value, sig. & Comments \\
\hline $\mathbf{H}_{1}:$ There is positive and significant effect of Customer Service Quality & $0.805, .000$ & Accepted \\
on Customer Satisfaction. & & \\
$\mathbf{H}_{2}:$ There is positive and significant effect of Tangibility on Customer & $0.215, .000$ & Accepted \\
Satisfaction. & & Accepted \\
$\mathbf{H}_{3}:$ There is a positive and significant effect of Reliability on Customer & $0.269, .000$ & \\
Satisfaction. & $0.219, .000$ & Accepted \\
$\mathbf{H}_{4}:$ There is positive and significant effect of Responsiveness on Cus- & & Accepted \\
tomer Satisfaction. & $0.196, .001$ & \\
$\mathbf{H}_{5}:$ There is positive and significant effect of Assurance on Customer & & Accepted \\
Satisfaction. & & \\
$\mathbf{H}_{6}:$ There is positive and significant effect of Empathy on Customer Sat- & $0.254, .000$ & \\
isfaction.
\end{tabular}

and fundamental perception of responsiveness and empathy is interaction between employees and customer with care and attention. In banking services employees perform major role. To satisfy customers the role of frontline staff becomes immensely vital cause of direct interaction with the customers. Employees should know the value of their job in service deliverance. Human resources aspects should be assured by authorities that they are managed perfectly by staff for service delivery. Moreover Tangibility aspect faced a lot of neutrality which means customer didnt observe the environment overwhelmed. Banks should work on their tangible aspects and ensure pleasant environment for the customers. Overall customers were happy with their banks and demonstrated constructive connection among all customer service quality traits and customer satisfaction.

\subsection{Future Directions}

Service quality effect needs be examined with other variables like customer loyalty, constructive word of mouth well as customer retention, etc. in Peshawar domain.

The prime motive of Pakistani financial institution business strategy should be the deliverance of best quality of services because customer service quality is the key element of customer satisfaction.

To evaluate customer service quality in Pakistani banks SERVQUAL should be used as an instrument of measurement by banks managers to calculate service quality. SERVQUAL is a reliable tool for determining service quality in Pakistani perspective.

To educate employees with the understanding of service customs and service supremacy banking sector need to allocate budgets and formulate strategies regarding employee training and development programs. Face-to-face or we can call it interpersonal communication and customer care factors in employees training and development programs should be paid a lot of attention in order to achieve the customers desires for personalized services. 


\section{References}

Alolayyan, M. N., Al-Hawary, S. I. S., Mohammad, A. A. S., and Al-Nady, B. A.-H. A. (2018). Banking service quality provided by commercial banks and customer satisfaction. a structural equation modelling approaches. International Journal of Productivity and Quality Management, 24(4):543-565.

Anderson, C. R. and Zeithaml, C. P. (1984). Stage of the product life cycle, business strategy, and business performance. Academy of Management journal, 27(1):5-24.

Anderson, E. W., Fornell, C., and Lehmann, D. R. (1994). Customer satisfaction, market share, and profitability: Findings from sweden. Journal of marketing, 58(3):53-66.

Anderson, E. W. and Sullivan, M. W. (1993). The antecedents and consequences of customer satisfaction for firms. Marketing science, 12(2):125143.

Angur, M. G., Nataraajan, R., and Jahera, J. S. (1999). Service quality in the banking industry: an assessment in a developing economy. International journal of bank marketing.

Beerli, A., Martin, J. D., and Quintana, A. (2004). A model of customer loyalty in the retail banking market. European journal of marketing.

Bharati, P. and Berg, D. (2005). Service quality from the other side: Information systems management at duquesne light. International Journal of Information Management, 25(4):367-380.

Bitner, M. J. (1992). Servicescapes: The impact of physical surroundings on customers and employees. Journal of marketing, 56(2):57-71.

Blanchard, R. and Galloway, R. (1994). Quality in retail banking. International Journal of Service Industry Management.

Bolton, R. N. and Drew, J. H. (1991). A multistage model of customers' assessments of service quality and value. Journal of consumer research, 17(4):375-384.
Chau, V. S. and Kao, Y.-Y. (2009). Bridge over troubled water or long and winding road? Managing Service Quality: An International Journal.

Chuah, C. W. and Sri Ramalu, S. (2011). Students satisfaction towards the university: Does service quality matters? International Journal of Education, 3(2):1-15.

Cronin Jr, J. J. and Taylor, S. A. (1992). Measuring service quality: a reexamination and extension. Journal of marketing, 56(3):55-68.

Gefen, D. (2002). Customer loyalty in e-commerce. Journal of the association for information systems, 3(1):2.

Gilbert, G. R. and Veloutsou, C. (2006). A crossindustry comparison of customer satisfaction. Journal of services marketing.

Grönroos, C. (2001). The perceived service quality concept-a mistake? Managing Service Quality: An International Journal.

Haq, W. and Muhammad, B. (2013). Customer satisfaction: A comparison of public and private banks of pakistan. In Proceedings of the Sixth International Conference on Management Science and Engineering Management, pages 515-523. Springer.

Jamal, A. and Naser, K. (2002). Customer satisfaction and retail banking: an assessment of some of the key antecedents of customer satisfaction in retail banking. International journal of bank marketing.

Johns, N. (1992). Quality management in the hospitality industry: Part 1 . definition and specification. International Journal of Contemporary Hospitality Management.

Kadir, H. A., Rahmani, N., and Masinaei, R. (2011). Impacts of service quality on customer satisfaction: study of online banking and atm services in malaysia. International Journal of Trade, Economics and Finance, 2(1):1.

Kassim, N. and Abdullah, N. A. (2010). The effect of perceived service quality dimensions on customer satisfaction, trust, and loyalty in ecommerce settings. Asia pacific journal of marketing and logistics. 
Kim, H.-R. (2005). Developing an index of online customer satisfaction. Journal of financial services marketing, 10(1):49-64.

Kotler, P. and Armstrong, G. (2012). Principles of marketing 14th edition. New Jearsey: Pearson Education Inc.

Kumar, S. A., Mani, B., Mahalingam, S., and Vanjikovan, M. (2010). Influence of service quality on attitudinal loyalty in private retail banking: An empirical study. IUP journal of management research, 9(4).

Lee, H., Lee, Y., and Yoo, D. (2000). The determinants of perceived service quality and its relationship with satisfaction. Journal of services marketing.

Loudon, D. L. and Bitta, A. J. (1993). Consumer behavior mcgraw-hill. Inc., New Jersey.

Lovelock, C. H. and Lovelock, C. H. (1996). Services marketing. Prentice Hall Upper Saddle River, NJ.

Mishkin, F. S. (2007). The economics of money, banking, and financial markets. Pearson education.

Munteanu, C., Ceobanu, C., Bobâlca, C., and Anton, O. (2010). An analysis of customer satisfaction in a higher education context. International Journal of Public Sector Management, 23(2):124140.

Newman, K. (2001). Interrogating servqual: a critical assessment of service quality measurement in a high street retail bank. International journal of bank marketing.

Oliva, R. and Sterman, J. D. (2001). Cutting corners and working overtime: Quality erosion in the service industry. Management Science, 47(7):894914.

Oliver, R. L. (1997). Emotional expression in the satisfaction response. Satisfaction: A behavioral perspective on the consumer, 291325.

Parasuraman, A., Berry, L. L., and Zeithaml, V. A. (1991). Perceived service quality as a customerbased performance measure: An empirical examination of organizational barriers using an extended service quality model. Human resource management, 30(3):335-364.
Parasuraman, A., Zeithaml, V. A., and Berry, L. L. (1985). A conceptual model of service quality and its implications for future research. Journal of marketing, 49(4):41-50.

Parker, C. and Mathews, B. P. (2001). Customer satisfaction: contrasting academic and consumers interpretations. Marketing Intelligence \& Planning.

Prahalad, C. K., Ramaswamy, V., et al. (2000). Coopting customer competence. Harvard business review, 78(1):79-90.

Santos, J. (2003). E-service quality: a model of virtual service quality dimensions. Managing Service Quality: An International Journal.

Stevens, G. C. and Johnson, M. (2016). Integrating the supply chain 25 years on. International Journal of Physical Distribution \& Logistics Management.

Streiner, D. L. (2003). Being inconsistent about consistency: When coefficient alpha does and doesn't matter. Journal of personality assessment, 80(3):217-222.

Swan, J. E. and Combs, L. J. (1976). Product performance and consumer satisfaction: A new concept: An empirical study examines the influence of physical and psychological dimensions of product performance on consumer satisfaction. Journal of marketing, 40(2):25-33.

Taylor, S. A. and Baker, T. L. (1994). An assessment of the relationship between service quality and customer satisfaction in the formation of consumers' purchase intentions. Journal of retailing, 70(2):163-178.

Wakefield, K. L. and Blodgett, J. G. (1999). Customer response to intangible and tangible service factors. Psychology $\mathcal{E}$ Marketing, 16(1):51-68.

Wang, Y., Lo, H.-P., and Hui, Y. V. (2003). The antecedents of service quality and product quality and their influences on bank reputation: evidence from the banking industry in china. Managing Service Quality: An International Journal.

Wisniewski, M. (2001). Using servqual to assess customer satisfaction with public sector services. Managing Service Quality: An International Journal. 
Yavas, U., Bilgin, Z., and Shemwell, D. J. (1997). Service quality in the banking sector in an emerging economy: a consumer survey. International journal of bank marketing.

Yee, R. W., Yeung, A. C., and Cheng, T. E. (2008). The impact of employee satisfaction on quality and profitability in high-contact service industries. Journal of operations management, 26(5):651668.

Yoo, D. K. and Park, J. A. (2007). Perceived service quality. International Journal of Quality \& reliability management.

Zahorik, A. J. and Rust, R. T. (1993). Customer sat- isfaction, customer retention, and market share. Journal of retailing, 69(2):193-215.

Zeithaml, V. A., Berry, L. L., and Parasuraman, A. (1988). Servqual: a multiple-item scale for measuring consumer perceptions of service quality. Journal of retailing, 64(1):12-40.

Zeithaml, V. A., Bitner, M. J., and Gremler, D. (1996). Services marketing. new york: Mcgrawhill.

Zeithaml, V. A., Bitner, M. J., Gremler, D. D., and Pandit, A. (2000). Services marketing: Integrating customer focus across the firm. 